\title{
Efficacy of the fumagillin analog TNP-470 for Nucleospora salmonis and Loma salmonae infections in chinook salmon Oncorhynchus tshawytscha
}

\author{
M. J. Higgins ${ }^{1}$, M. L. Kent ${ }^{1, *}$, J. D. W. Moran ${ }^{1}$, L. M. Weiss ${ }^{2}$, S. C. Dawe ${ }^{1}$ \\ ${ }^{1}$ Department of Fisheries and Oceans, Pacific Biological Station, Nanaimo, British Columbia V9R 5K6, Canada \\ ${ }^{2}$ Department of Pathology, Albert Einstein College of Medicine, Bronx, New York 10461, USA
}

\begin{abstract}
Oral treatment with fumagillin is effective for controlling various microsporean and myxosporean infections in fish. We tested a synthetic analog of fumagillin, TNP-470 (Takeda Chemical Industries), for its efficacy against 2 microsporean pathogens of salmon: Loma salmonae and Nucleospora salmonis. Chinook salmon Oncorhynchus tshawytscha were experimentally infected with either L. salmonae (per os) or N. salmonis (intraperitoneal, i.p., injection) and held in fresh water at $15^{\circ} \mathrm{C}$. Fish were then divided into 3 replicate groups: untreated or treated orally at $1.0 \mathrm{mg}$ or at $0.1 \mathrm{mg} \mathrm{drug} \mathrm{\textrm {kg } ^ { - 1 }}$ fish $\mathrm{d}^{-1}$. With $L$. salmonae, the high dose fish had 0.32 xenomas $\mathrm{mm}^{-2}$ of gill tissue compared to controls at 24.5 xenomas per $\mathrm{mm}^{2}$. With $\mathrm{N}$. salmonis infections, untreated fish exhibited $100 \%$ infection, showed prominent clinical signs (e.g. renal swelling, anaemia), and high mortality. In contrast, fish treated at $1.0 \mathrm{mg} \mathrm{kg} \mathrm{m}^{-1}$ showed no clinical signs, and $16 \%$ of those treated at $0.1 \mathrm{mg} \mathrm{kg}^{-1}$ showed only mild gross pathological changes. With the treated groups, over $50 \%$ of the fish exhibited extremely light infections, even with high dose treatments, but no mortalities were attributed to $N$. salmonis infections.

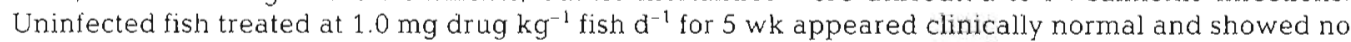
reduction in growth. However, about half of these fish exhibited atrophy of the renal interstitial hematopoietic tissue.
\end{abstract}

KEY WORDS: TNP-470 Microsporidia Nucleospora salmonis - Loma salmonae

\section{INTRODUCTION}

Nucleospora salmonis (= Enterocytozoon salmonis) Hedrick, Groff and Baxa, 1991 and Loma salmonae (Putz, Hoffman and Dunbar, 1965) are 2 common microsporean pathogens of salmonids. The former has been associated with anaemia (Elston et al. 1987), lymphoblastosis (Hedrick et al. 1990, Morrison et al. 1990), and a plasmacytoid leukemia (Kent et al. 1990) in chinook salmon Oncorhynchus tshawytscha. The infection is associated with exopthalmos, gill pallor, enlargement of the kidney and spleen, ascites and hyperemia of the pyloric caeca. L. salmonae infects primarily the gills in several Oncorhynchus species, including chinook salmon, where it forms xenomas.

·Addressee for correspondence. E-mail: kentm@dfo-mpo.gc.ca
These xenomas ultimately rupture, causing severe inflammatory changes (Kent et al. 1989, Speare et al. 1989). L. salmonae is an economically important microsporean parasite of hatchery-reared salmonids in fresh water (Putz et al. 1965. Hauck 1984, Markey et al. 1994, Bruno et al. 1995). Infections of L. salmonae can persist after transfer to sea water, and have caused disease in seawater pen-reared salmon (Kent et al. 1989, Speare et al. 1989). Direct transmission occurs with both parasites, and laboratory transmission is readily reproduced (Hedrick et al. 1991, Baxa-Antonio et al. 1992, Kent et al. 1995).

The use of fumagillin, a natural product of Aspergillus fumigatus, has proven successful for the control of microsporidia infections, including Nucleospora salmonis (cf. Hedrick et al. 1991) and Loma salmonae (cf. Kent \& Dawe 1994). An analog of fumagillin, TNP- 
470 , is a potent anti-angiogenesis agent (Kusaka et al. 1994). Furthermore, TNP-470 has been shown to be effective in laboratory studies against the mammalian microsporean pathogens Encephalitozoon intestinalis, Vittaforma corneae (cf. Didier 1997), E. cuniculi and E. hellem (Coyle et al. 1998). In this study, we treated chinook salmon that were experimentally infected with either $N$. salmonis or L. salmonae with TNP-470 to evaluate the efficacy of this drug in controlling these infections.

\section{MATERIALS AND METHODS}

TNP-470. TNP-470 was provided by TAP Pharmaceuticals, Deerfield, IL, USA, as a concentrated powder. The appropriate amount of drug was dissolved in $10 \mathrm{ml}$ of $95 \%$ ethanol and sprayed directly onto approximately $50 \mathrm{~g}$ dry pellet feed to achieve $10 \mathrm{mg}$ and $100 \mathrm{mg}$ drug $\mathrm{kg}^{-1}$ feed. Fish were then fed at $1 \%$ body weight $\mathrm{d}^{-1}$, resulting in dosages of $0.1 \mathrm{mg}$ or $1.0 \mathrm{mg}$ drug $\mathrm{kg}^{-1}$ fish $\mathrm{d}^{-1}$. A light spraying of corn oil applied over the TNP-470 coating helped ensure adhesion of the drug to the feed. For both microsporean infections, each drug dosage was duplicated (i.e. 2 tanks each at 0.1 and $1.0 \mathrm{mg} \mathrm{kg}^{-1}$ ) and 2 tanks were fed untreated feed as a control. The tanks (42 l) received flowing fresh water at $15^{\circ} \mathrm{C}$.

Nucleospora salmonis. Kidneys and spleens positive for Nucleospora salmonis infections were collected from a previously infected stock of salmon held at the Pacific Biological Station, Nanaimo, British Columbia. Infected tissues collected from donor fish were placed in sterile saline (1:10), and gently forced through a $50 \mu \mathrm{m}$ mesh screen sieve with a rubber tipped syringe plunger to disrupt the tissue without harming $N$. salmonis. The resultant slurry was injected intraperitoneally into parasite-free chinook salmon pre-smolts (avg. wt $4.6 \mathrm{~g}$ ). Each fish received $0.25 \mathrm{ml}$ of the $N$. salmonis mixture; then fish were divided into the tanks. A total of 25 fish treatment ${ }^{-1}$ was used, and each tank held 12 to 13 fish. Injected fish were then maintained on a dry commercial feed for $12 \mathrm{~d}$ post-injection (p.i.) before the TNP-470 treated feed was administered. The drug was administered for $6 \mathrm{wk}$, and the study was terminated at $10 \mathrm{wk}$ p.i.

At the end of the study fish were examined for gross pathological signs of infection before removing tissues for histological evaluation, characterised by pallor of the gills (indicating anaemia), and reno-splenomegaly. Kidney and spleen tissues were collected and preserved in Davidson's solution and were processed for routine histology. Density of infection was determined by counting the numbers of parasites in hemocyte nuclei. present within 10 random fields of view at $1000 \times$ magnification $(0.176 \mathrm{~mm}$ diameter $)$ in histologi- cal sections. The total parasite count was then converted to parasites per $\mathrm{mm}^{2}$ of kidney or spleen tissue Gross observations were not directly correlated with density values for individual fish because kidneys were processed in groups of 3 in paraffin blocks.

Loma salmonae. Trial 1: Gill tissue with numerous Loma salmonae xenomas was collected from a stock of previously infected chinook and coho salmon Oncorhynchus kisutch held at the Pacific Biological Station. Infected gill tissue was removed from each fish, chopped finely with scissors into dechlorinated fresh water and homogenized with a Polytron generator (Brinkmann Instruments Co., Rexdae, Ontario, Canada). A total of 120 chinook salmon (avg. wt $24.0 \mathrm{~g}$ ) were intubated with $0.25 \mathrm{ml}$ of spore suspension at a rate of 2 to $3 \times 10^{5} \mathrm{~L}$. Salmonae spores $\mathrm{fish}^{-1}$. Fish were then divided into the 6 tanks at 20 fish $\operatorname{tank}^{-1}$ (40 fish per treatment regime). The drug was administered for 6 wh starting $7 \mathrm{~d}$ p.i., and the expcriment was terminated and fish collected at $8 \mathrm{wk}$ p.i.

The severity of infection was represented by xenoma density, which was determined by counting the xenomas in the outer left gill arch in a wet mount preparation in $3 \times 100$ fields, and the results were converted to xenomas per $\mathrm{mm}^{2}$.

Trial 2: A second trial was added to confirm the Loma salmonae results; however, the low dose was in-

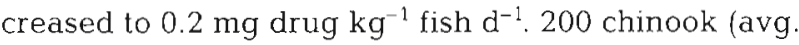
wt $17.0 \mathrm{~g}$ ) were intubated with $0.25 \mathrm{ml}$ of spore suspension at a rate of 2 to $3 \times 10^{5} \mathrm{~L}$. salmonae spores fish $^{-1}$. Fish were then divided into the 10 tanks at 20 fish $\operatorname{tank}^{-1}$ (40 fish per treatment regime). Uninfected treated (high dose) and untreated replicates were included in this trial to determine possible toxic effects of the drug. The drug was administered for 6 wk starting $7 \mathrm{~d}$ p.i., and the experiment was terminated and fish collected at $8 \mathrm{wk}$ p.i.

Statistics. A nested 1-way ANOVA with the Tukey Honestly Significantly Different (HSD) test compared weight differences between mean infection rates of the grouped replicates of the 2 treatments and control groups for Nucleospora Salmonis and Loma salmonae. To look at any effects the drug may have upon feeding behaviour, the uninfected non-treated groups were compared to uninfected drug-treated groups using a 1way ANOVA.

\section{RESULTS}

TNP -470 treatments at both levels had marked effects on the presentation of clinical disease and gross pathologic changes associated with Nucleospora salmonis infections. While all controls exhibited clinical disease, only $5 / 25$ fish among the low dose groups exhibited 
Table 1. Nucleospora salmonis infecting Oncorhynchus tshawytscha. Mean density of $N$. salmonis organisms in hemocyte nuclei of the kidney and spleen tissue of chinook salmon treated with TNP-470

\begin{tabular}{|c|c|c|c|c|c|c|}
\hline \multirow[t]{2}{*}{ Parasite } & \multicolumn{2}{|c|}{$\begin{array}{c}\text { High dose } \\
\text { (1.0 mg drug kg-1 fish) }\end{array}$} & \multicolumn{2}{|c|}{$\begin{array}{c}\text { Low dose } \\
\left(0.1 \mathrm{mg} \mathrm{drug} \mathrm{kg}^{-1} \text { fish) }\right.\end{array}$} & \multicolumn{2}{|c|}{ Control } \\
\hline & Tank 1 & Tank 2 & Tank 1 & Tank 2 & Tank 1 & Tank 2 \\
\hline \multicolumn{7}{|l|}{ N. salmonis } \\
\hline Kidney sections $\left(\bar{x} / \mathrm{mm}^{2}\right)$ & $0.75 \pm 0.50$ & $2.27 \pm 0.65$ & $187.82 \pm 164.69$ & $36.83 \pm 24.76$ & $1707.81 \pm 401.62$ & $1595.37 \pm 191.40$ \\
\hline Spleen sections $\left(\bar{x} / \mathrm{mm}^{2}\right)$ & $1.51 \pm 0.63$ & $1.14 \pm 0.58$ & $150.32 \pm 129.26$ & $109.85 \pm 77.61$ & $1.147 .92 \pm 318.02$ & $1103.24 \pm 128.61$ \\
\hline Infection $(\%)$ & $4 / 11(36)$ & $6 / 11(54)$ & $12 / 13(92)$ & $10 / 11(91)$ & $8 / 8(100)$ & $9 / 9(100)$ \\
\hline Gross pathology $(\%)$ & $0 / 12(0)$ & $0 / 11(0)$ & $2 / 12(17)$ & $3 / 13(23)$ & $9 / 9(100)$ & $9 / 9(100)$ \\
\hline
\end{tabular}

clinical disease and all of the 'high dose' fish appeared normal (Table 1). At 6 wk. p.i., untreated fish began to exhibit clinical signs of the $N$. salmonis infection and mortality. Gram-stained kidney imprints obtained from dead fish from untreated tanks confirmed the presence of the parasite. These fish typically exhibited exopthalmos and anaemia, while fish from both treated groups were essentially normal. The untreated fish showed $28 \%$ mortality due to $N$. salmonis infections before the experiment was terminated. At the end of the experiment, histological assessment of kidneys $\left(F_{3.59}=57.7 ; \mathrm{p}<0.001\right)$ and spleens $\left(F_{3.59}=40.8 ; \mathrm{p}<0.001\right)$ demonstrated a marked ( 1 to $3 \log$ ) reduction in the densities of N. salmonis infections in both the 0.1 and $1.0 \mathrm{mg}$ doses compared to controls (Table 1). However, many of the treated fish in both groups still exhibited light infections. During the trials, 2 fish were lost from the high-dose tank due to fish jumping from tanks, neither of which showed any clinical signs of the disease.

TNP-470 was also effective at reducing Loma salmonae infections. The incidence of infection was reduced in both the low and high doses compared in the first trial, and the mean density of xenomas found in the gills was significantly reduced $\left(F_{3,106}=49.2 ; \mathrm{p}<0.001\right)$ (Table 2). However, a significant difference $\left(F_{3,106}=5.65\right.$; $p<0.05$ ) among control replicates was noted and was attributed to 2 distinct outliers. Removal of these individuals resulted in equity within all groups. No mor- bidity or mortality was associated with L. salmonae infections in any treatment groups, but a few fish died in each group in the first trial shortly after the experiment was initiated, which was not attributed to the infection.

A lighter infection from Loma salmonae in the second trial made it necessary to count all xenomas on each gill harvested (Table 2). Gill area was measured and number of parasites was then converted to parasites per $\mathrm{mm}^{2}$ gill tissue to standardise results from the 2 experiments. A mean of $0.58 \pm 0.18$ and $0.67 \pm$ 0.12 xenomas per $\mathrm{mm}^{2}$ gill tissue was counted from control tanks 1 and 2, respectively, whereas no xenomas were present on either the low or the high dose groups $\left(F_{3,113}=39.69 ; \mathrm{p}<0.001\right)$.

Kidneys and spleens of treated fish showed no discernible toxicopathic changes at the low dose; however, approximately one-half of the fish fed the high dose exhibited a decrease in hematopoietic tissue (Figs. 1 \& 2). No significant change in weight was noted by the end of these studies in uninfected treated groups compared with uninfected non-treated groups (Table 2)

\section{DISCUSSION}

In recent years several researchers have shown that oral treatment with fumagillin is effective for both

Table 2. Loma salmonae infecting Oncorhynchus tshawytscha. Mean density of $L$. salmonae xenomas in the gills of chinook salmon treated with TNP-470. Trial 1 treated at $0.1 \mathrm{mg} \mathrm{drug} \mathrm{kg}^{-1}$ fish; Trial 2 treated at $0.2 \mathrm{mg}$ drug $\mathrm{kg}^{-1}$ fish. ND: not done

\begin{tabular}{|c|c|c|c|c|c|c|}
\hline \multirow[t]{2}{*}{ Parasite } & \multicolumn{2}{|c|}{$\begin{array}{c}\text { High dose } \\
\left.\text { (1.0 mg drug kg } \mathrm{kg}^{-1} \mathrm{fish}\right)\end{array}$} & \multicolumn{2}{|c|}{$\begin{array}{c}\text { Low dose } \\
\text { (0.1 mg drug } \mathrm{kg}^{-1} \text { fish) }\end{array}$} & \multicolumn{2}{|c|}{ Control } \\
\hline & Tank 1 & Tank 2 & Tank 1 & Tank 2 & Tank 1 & Tank 2 \\
\hline \multicolumn{7}{|l|}{ L. salmonae (Trial 1) } \\
\hline Gills (xenomas $/ \mathrm{mm}^{2}$ gill tissue) & $0.79 \pm 0.05$ & $0.55 \pm 0.36$ & $15.71 \pm 3.46$ & $14.48 \pm 2.92$ & $39.19 \pm 4.93$ & $21.12 \pm 2.87$ \\
\hline Infection $(\%)$ & $2 / 19(11)$ & $3 / 20(15)$ & $18 / 18(100)$ & $20 / 20(100)$ & $13 / 14(93)$ & $18 / 19(95)$ \\
\hline \multicolumn{7}{|l|}{ L. salmonae (Trial 2) } \\
\hline Gill (xenomas $/ \mathrm{mm}^{2}$ gill tissue) & 0 & 0 & 0 & 0 & $0.58 \pm 0.18$ & $0.67 \pm 0.12$ \\
\hline Infection $(\%)$ & $0 / 20(0)$ & $0 / 20(0)$ & $0 / 20(0)$ & $0 / 20(0)$ & $16 / 17(94)$ & $18 / 18(100)$ \\
\hline $\bar{x}$ wt fish (g) before and (after) treatment & $16.4(18.3)$ & $16.5(17.2)$ & ND & ND & $17.5(19.5)$ & $17.1(18.4\}$ \\
\hline
\end{tabular}



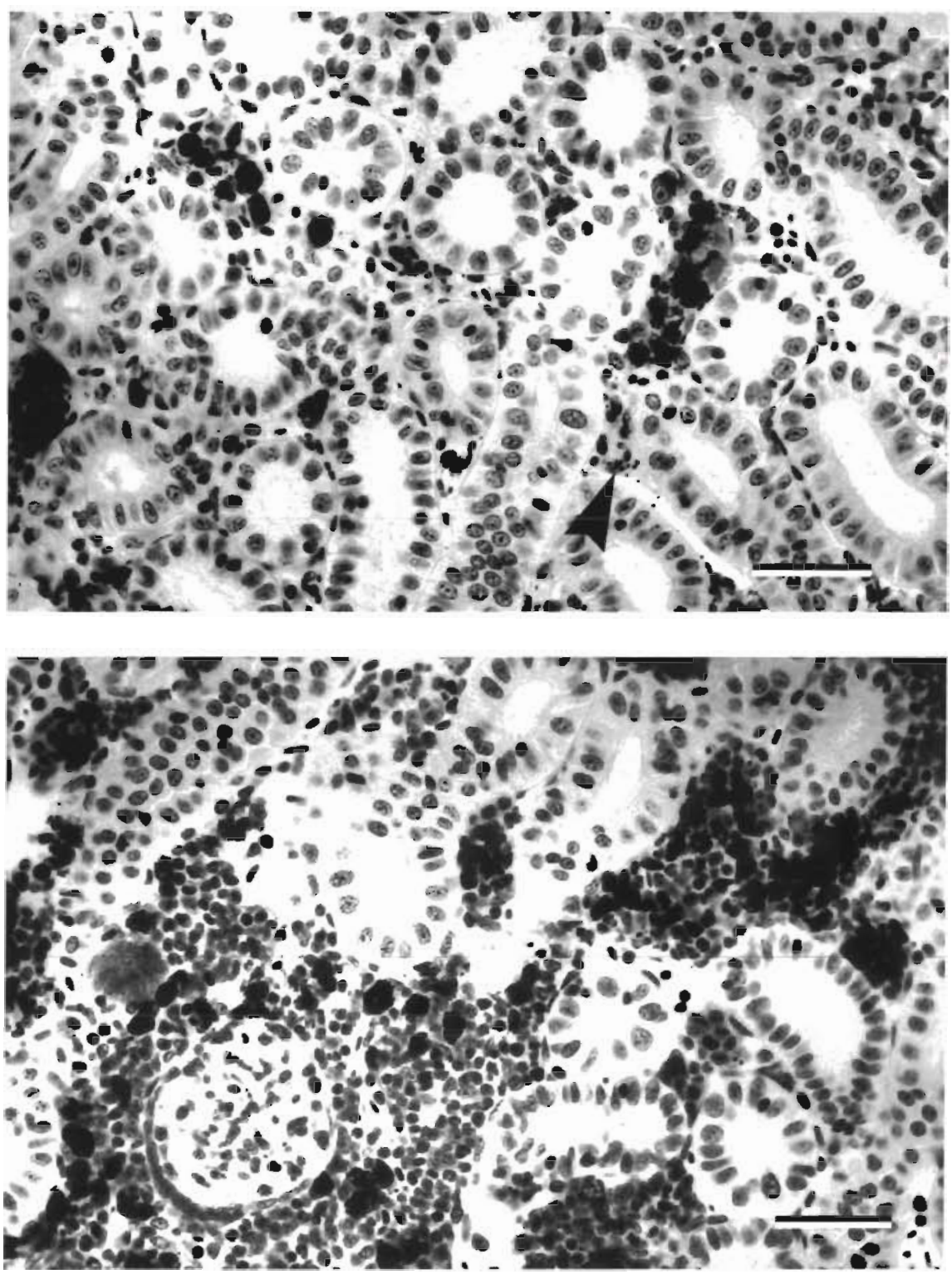

Fig. 1. Oncorhynchus tshawytscha Posterior kidney of fish fed with high dose TNP-470 feed. Note atrophy and necrosis (arrowhead) of hematopoietic tissue. Scale bar $=50 \mu \mathrm{m}$. Hematoxylin and eosin microsporean and myxosporean infections of fishes, including Loma salmonae and Nucleospora salmonis (cf. Hedrick et al. 1991, Kent \& Dawe 1994). Our study showed that TNP-470 had a positive impact on both $N$. salmonis and $L$. salmonae infections. For $N$. salmonis, feeding the drug was associated with a dramatic decrease in the pathological changes associated with the infections. The drug also reduced the severity of $L$. salmonae infections. Because some fish still exhibited light infections caused by both parasites shortly after the treatment, further studies should be conducted to determine if clinical infections may occur several weeks or months after therapy is completed.

The treatment regime employed in this study did not appear to affect growth, and uninfected fish treated at the high dose appeared healthy. However, histological examination of the kidney revealed atrophy of the hematopoietic tissue of the kidney interstitium in about half of the fish. These findings are consistent with those found by Wishkovsky et al. (1990), where doses of $10.0 \mathrm{mg}$ fumagillin $\mathrm{kg}^{-1}$ fish produced a severe decrease in the renal hematopoietic tissue of rainbow trout Oncorhynchus mykiss after an $8 \mathrm{wk}$ treatment. Application of TNP-470 at the low dose rate $10.1 \mathrm{mg}$ drug $\mathrm{kg}^{-1}$ of fish) represents about a 30 -fold reduction of in treatment concentration compared to the dosage of fumagillin usually used for treating salmonid fishes (i.e. $3.0 \mathrm{mg}$ drug $\mathrm{kg}^{-1}$ fish $\mathrm{d}^{-1}$ ). This suggests that this analog may be effective at low doses, and thus may ultimately reduce the costs and potential side effects for treating microsporean infections in fish. 
Acknowledgements. This study was funded in part by NSERC Strategic Grants STR 180990 and TAP Pharmaceuticals

\section{LITERATURE CITED}

Baxa-Antonio D, Groff JM. Hedrick RP (1992) Experimental horizontal transmission of Enterocytozoon salmonis to chinook salmon. Oncorhynchus tshawytscha. J Protozool 39(6):699-702

Bruno DW, Collins RO, Morrison CM (1995) The occurrence of Loma salmonae (Protozoa: Microspora) in farmed rainbow trout, Oncorhynchus mykiss Walbaum, in Scotland. Aquaculture 133:341-344

Coyle C, Kent ML, Tanowitz HB, Wittner M, Weiss LM (1998) TNP-470 is an effective anti-microsporidial agent. J Infect Dis 177:515-518

Didier ES (1997) Effects of albendazole, fumagillin, and TNP-470 on microsporidial replication in vitro. Antimicrob Agents Chemother 41:1541-1546

Elston RA, Kent ML, Harrell LW (1987) An intranuclear microsporidan associated with acute anemia in chinook salmon, Oncorhynchus tshawytscha. J Protozool 34: $274-277$

Hauck AK (1984) A mortality and associated tissue reactions of chinook salmon, Oncorhynchus tshawytscha (Walbaum), caused by the microsporidian Loma sp. J Fish Dis 7:217-229

Hedrick RP, Groff JM, Baxa DV (1991) Experimental infections with Enterocytozoon salmonis Chilmonczyk, Cox, Hedrick (Microsporea): an intranuclear microsporidium from chinook salmon Oncorhynchus tshawytscha. Dis Aquat Org 10:103-108

Hedrick RP, Groff JM, McDowell TS, Willis M, Cox WT (1990) Hematopoietic intranuclear microsporidian infections with features of leukemia in chinook salmon Oncorhynchus tshawytscha. Dis Aquat Org 8:189-197

Editorial responsibility: Wolfgang Körting,

Hannover, Germany
Kent ML, Dawe SC (1994) Efficacy of Fumagillin DCH against experimentally induced Loma salmonae (Microsporea) infections in chinook salmon Oncorhynchus tshawytscha. Dis Aquat Org 20:231-233

Kent ML, Dawe SC, Speare DJ (1995) Transmission of Loma salmonae (Microsporea) to chinook salmon in sea water Can Vet J 36:98-102

Kent ML, Elliott DG, Groff JM, Hedrick RP (1989) Loma salmonae (Protozoa: Microspora) infections in seawater reared coho salmon, Oncorhynchus kisutch. Aquaculture 80:211-222

Kent ML, Groff JM, Traxler GS, Zinkl JG, Bagshaw JW (1990) Plasmacytoid leukemia in seawater reared chinook salmon Oncorhynchus tshawytscha. Dis Aquat Org 8:199-209

Kusaka M, Sudo K, Matsutani E, Kozai Y, Marui S, Fujita T, Ingber D. Folkman J (1994) Cytostatic inhibition of endothelial cell growth by the angiogenesis inhibitor TNP-470 (AGM-1470). Br J Cancer 69:212-216

Markey PT, Blazer VS, Ewing MS, Kocan KM (1994) Loma sp. in salmonids from the eastern United States: associated lesions in rainbow trout. J Aquat Anim Health 6:318-328

Morrison JK, MacConnell E, Chapman PF, Westgard RL (1990) A microsporidium-induced lymphoblastosis in chinook salmon Oncorhynchus tshawytscha. Dis Aquat Org 8: 99-104

Putz RE, Hoffman GL, Dunbar CE (1965) Two new species of Plistophora (Microsporidea) from North American fish with a synopsis of Microsporidea of freshwater and euryhaline fishes. J Protozool 12:228-236

Speare DJ, Brackett J, Ferguson HW (1989) Sequential pathology of the gills of coho salmon with a combined diatom and microsporidian gill infection. Can Vet J 30 . 571-575

Wishkovsky A, Groff JM, Lauren DJ, Toth RJ, Hedrick RP (1990) Efficacy of fumagillin against proliferative kidney disease and its toxic side effects in rainbow trout (Oncorhynchus mykiss) fingerlings. Fish Pathol 25:141-146

Submitted: March 10, 1998; Accepted: May 13, 1998

Proofs received from author(s): July 27, 1998 